УДК 574.24.581.132

\title{
А.В. ЛИФАНЧУК
}

Южное отделение Ин-та океанологии им. П.П. Ширшова РАН, ул. Просторная, 1, Геленджик 353467, Краснодарский край, Россия e-mail: lifanchuk.anna@mail.ru

\section{МОРФОЛОГИЧЕСКАЯ СТРУКТУРА ДОМИНИРУЮЩИХ ВИДОВ ДИАТОМОВЫХ ВОДОРОСЛЕЙ СЕВЕРО-ВОСТОЧНОЙ ЧАСТИ ЧЁРНОГО МОРЯ}

Установлено влияние концентраций элементов минерального питания на морфологическую структуру (количество клеток в цепи) и продукционные свойства водорослей лидирующего комплекса фитопланктона северо-восточной части Чёрного моря в 2009-2012 гг. В опытах с добавками азота и фосфора у диатомей Dactyliosolen fragilissimus (Bergon) Hasle и Sceletonema costatum (Grev.) Cleve увеличивалось количество клеток в цепи при высоких концентрациях обоих элементов минерального питания в культуре. Повышение концентрации фосфора в среде при низком содержании азота вызывало увеличение клеточной цепи у Leptocylindrus danicus Cleve и Thalassionema nitzschioides Grunow. Добавки элементов минерального питания не влияли на изменения в клеточной цепи диатомеи Pseudo-nitzschia pseudodelicatissima (Hasle) Hasle. Эксперименты показали высокую взаимосвязь между численностью клеток и количеством клеток в цепи у диатомей Th. nitzschioides, D. fragilissimus и S. costatum. У L. danicus взаимосвязь между этими параметрами отсутствовала, а у P. pseudodelicatissima корреляция была очень слабой. Интенсификация роста биомассы диатомей происходила при одновременной добавке азота и фосфора.

Кл юч е в ы е с л о в а : фитопланктон, Чёрное море, азот, фосфор, количество клеток в цепи.

\section{Введение}

В Черном море диатомовые водоросли практически всегда входят в состав лидирующего комплекса видов, определяющего численность или биомассу всего фитопланктона. Для видовой структуры фитопланктона характерна сезонная и межгодовая изменчивость (Паутова и др., 2007; Микаэлян и др., 2011). С другой стороны, по видовой структуре можно оценить как продукционные свойства фитопланктона, так и условия среды. Смена структуры - достаточно сложный и продолжительный процесс. Изменение условий среды, как правило, отражается на морфологии клеток, и она, по всей видимости, будет предшествовать предстоящей смене всего лидирующего комплекса.

Морские диатомовые водоросли обладают большой морфологической изменчивостью. Все виды диатомей, по определению, обладают кремнистыми клеточными стенками, но их морфология может варьировать от одной клетки к неограниченному числу клеток, образующих клеточные цепи (Прошкина-Лавренко, 1955). Однако факторы, влияю-

(C) А.В. Лифанчук, 2013 
щие на количество клеток в цепи диатомей, остаются недостаточно изученными. Очевидно, что наиболее существенным будет лимитирующий фактор, т.е. фактор, находящийся в относительном минимуме.

Обычно лимитирующий фактор определяют по соотношению Редфилда (Redfield, 1934). Соотношение углерода, азота и фосфора в веществе океанического планктона в среднем составляет 106:16:1. Соотношение Редфилда - это удобная точка отсчета, позволяющая судить о том, какой конкретный элемент - азот или фосфор - ограничивает в том или ином месте развитие фитопланктона (углерод не принимается во внимание, так как в морской среде он находится в больших количествах) (Redfield et al., 1963). Однако этот гидрохимический показатель не всегда имеется в распоряжении исследователей, и прежде всего фитопланктологов. Кроме того, этот показатель не всегда точно указывает на лимитирующий фактор (Silkin et al., 2009).

Целью данной работы было установление взаимосвязи между продукционными свойствами водорослей и количеством клеток в цепи диатомей. Также сделана попытка выявить лимитирующий фактор по количеству клеток в цепи диатомовых водорослей. Для этого в накопительной культуре природного фитопланктона изучали продукционные свойства и соответствующие им морфологические параметры для доминирующих видов диатомей северо-восточной части Черного моря Pseudo-nitzchia pseudodelicatissima, Leptocylindrus danicus, Thalassionema nitzschioides, Dactyliosolen fragilissimus и Sceletonema costatum.

\section{Материалы и методы}

С весны 2009 г. до ноября 2012 г. проводили эксперименты с накопительной культурой природной популяции фитопланктона в береговой лаборатории ЮО ИО РАН (г. Геленджик). Объектом исследования служила смешанная культура водорослей, полученная на основе природного сообщества фитопланктона. Пробы собирали с борта научно-исследовательского судна «Ашамба». Отбор проб проводили с горизонта 0 м на станции стандартного разреза от Голубой бухты к центру моря. Станция располагалась над глубиной 50 м (район срединного шельфа). Образцы выращивали в колбах Эрленмейера емкостью 500 мл (объем среды 200 мл) в термолюминостате, где температура среды соответствовала температуре морской воды в месте отбора проб. Интенсивность падающего света составляла 58-61 мкмоль/м² режим - 16:8.

Идентификацию видов и подсчет числа клеток проводили ежедневно с помощью светового микроскопа в счетной камере Ножотта объемом 0,05 мл. Биомассу рассчитывали методом «истинного объема» (Киселев, 1969), при этом использовали данные собственных измерений. На основе установленных объемов клеток водорослей и учитывая их удельный вес, определяли среднюю массу всех клеток фитопланктона. Далее, умножая среднюю массу на численность клеток, получали их биомассу. Опыты проводили с использованием метода планирования 
экспериментов, которые позволяют получать уравнения регрессии, отражающие действие выбранных факторов на изучаемый параметр (Максимов, Федоров, 1969). В экспериментах применяли периодический (накопительный) режим культивирования. Добавку элементов минерального питания (нитратов в форме $\mathrm{KNO}_{3}$ и фосфатов в форме $\mathrm{Na}_{2} \mathrm{HPO}_{4}$ ) проводили в начале эксперимента по единой схеме, представленной в табл. 1.

Таблица 1

План экспериментов по изучению влияния добавок элементов минерального питания на продукционные свойства и морфологические параметры диатомей

\begin{tabular}{|c|c|c|}
\hline Номер колбы & Нитраты $\mathrm{KNO}_{3} 12,1-14,3$ мкM & Фосфаты $\mathrm{Na}_{2} \mathrm{HPO}_{4} 0,81-1$ мкM \\
\hline 1 & - & - \\
\hline 2 & + & - \\
\hline 3 & - & + \\
\hline 4 & + & + \\
\hline
\end{tabular}

В результате экспериментов получали кривую накопления клеток (или биомассы), для расчета уравнений регрессии использовали значение этих параметров в стационарной фазе роста (Силкин, Хайлов, 1988).

\section{Результаты}

Основными видами диатомей, образующими клеточные цепи, за период исследования были Pseudo-nitzchia pseudodelicatissima, Leptocylindrus danicus, Dactyliosolen fragilissimus, Sceletonema costatum и Thalassionema nitzschioides. Эти водоросли входили в лидирующий комплекс видов в различные сезоны и годы (Паутова и др., 2007; Силкин и др., 2013).

Диатомовая водоросль Leptocylindrus danicus входила в лидирующий комплекс фитопланктона шельфовой зоны северо-восточной части Чёрного моря осенью 2010-2011 гг. Динамика роста её биомассы близка к классической (логистической) кривой накопления клеток в периодической культуре. На рис. 1 показан результат эксперимента, проведенного 13.09.2011 г. В накопительную культуру добавляли фосфор и азот.

В эксперименте 15.09.2010 г. с добавкой в накопительную культуру водорослей только фосфора развитие Leptocylindrus danicus происходило на третий день эксперимента (рис. 2).

Численность клеток L. danicus составила 1,6·10 клеток в цепи - 8. Максимальные количество клеток в цепи (15) и численность $\left(1,6 \cdot 10^{6}\right.$ кл./л) отмечены на восьмой день эксперимента.

Взаимосвязь количества клеток цепи и численности клеток диатомеи L. danicus незначительна, коэффициент детерминации линейной функции составляет 0,0848 (рис. 3, a), а экспоненциальной $-0,0564$. В данном эксперименте количество клеток в цепи диатомеи L. danicus не зависело от численности клеток. 


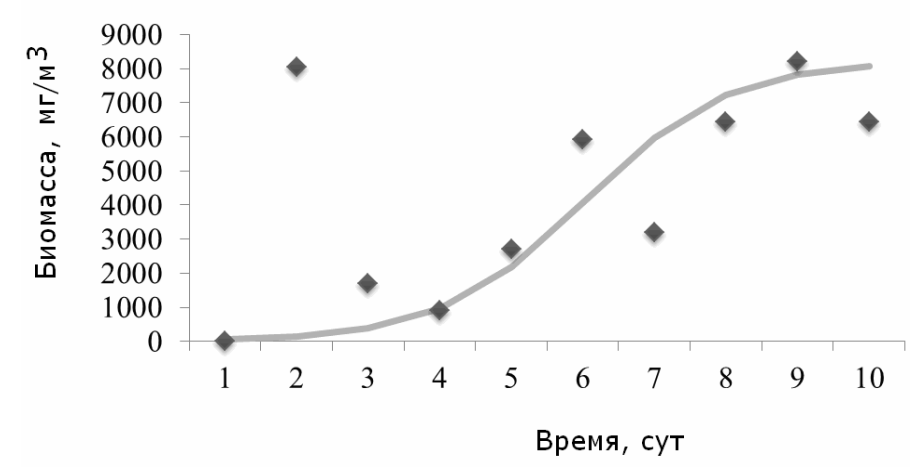

Рис. 1. Рост биомассы Leptocylindrus danicus в эксперименте 13.09.2011 г. и аппроксимация экспериментальных данных логистической кривой. В качестве добавки использовали фосфор и азот

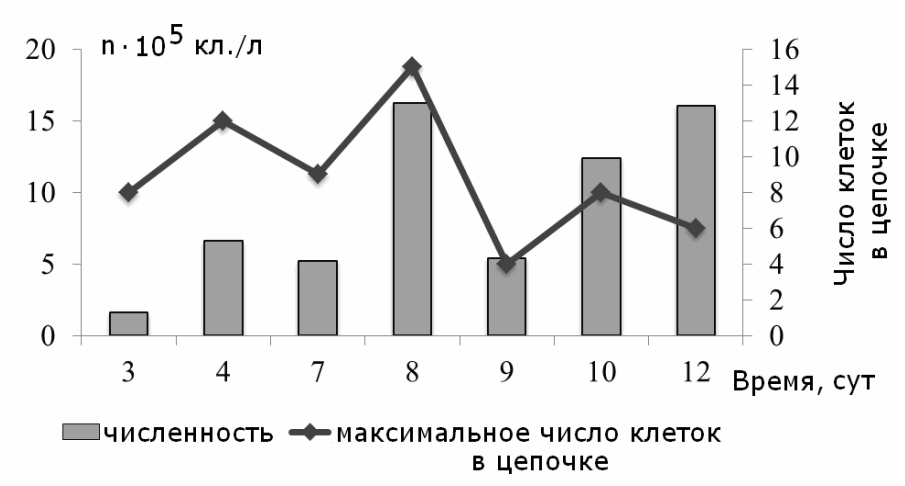

Рис. 2. Численность и количество клеток в цепи Leptocylindrus danicus в эксперименте 15.09.2010 г. В качестве добавки использовали фосфор

Для лучшего понимания влияния элементов минерального питания на продукционные свойства и морфологическую структуру лидирующих видов фитопланктонного сообщества рассчитывали уравнения регрессии (табл. 2).

Из уравнений следует, что только при совместной добавке азота и фосфора (сентябрь 2010-2011 гг.) происходит увеличение биомассы $L$. danicus и, соответственно, увеличение доли данного вида в сообществе. В октябре 2011 г. добавка азота и фосфора сравнима с ошибкой эксперимента. К этому времени данный вид не получил достаточного развития в природе и его биомасса в исходной культуре была очень низкой. 

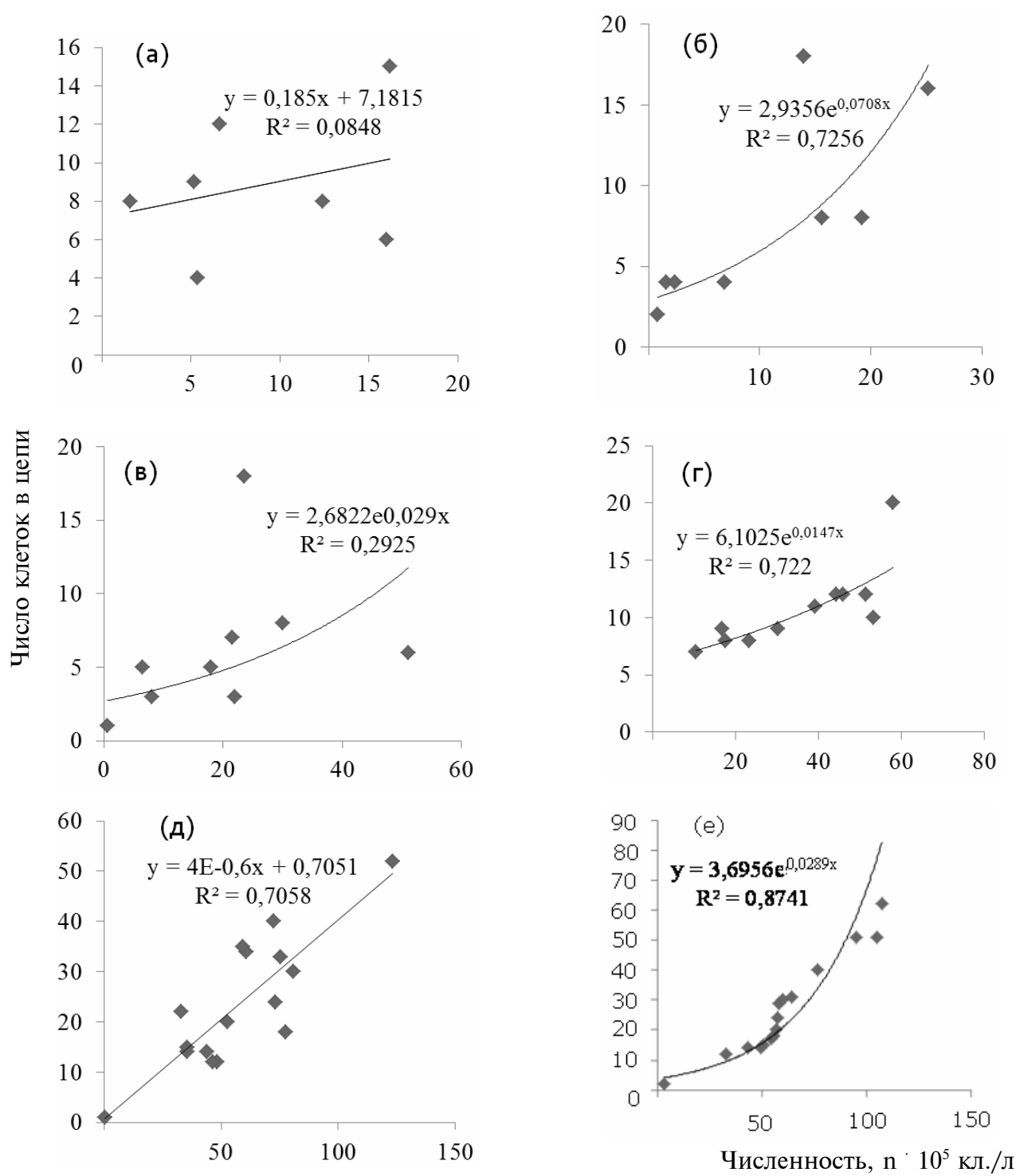

Рис. 3. Взаимосвязь количества клеток в цепи и численности клеток Leptocylindrus danicus (a), Thalassionema nitzschioides (б), Pseudo-nitzchia pseudodelicatissima (в), Sceletonema costatum (2), Dactyliosolen fragilissimus $(\partial, e)$

Такой морфологический параметр для $L$. danicus, как количество клеток в цепи оказался чувствителен к концентрации фосфора в среде. Из уравнений регрессии следует, что в сентябре 2010-2011 гг. фосфор был лимитирующим элементом. Добавка азота не влияла на изменение количества клеток в цепи в осенний период (см. табл. 3). 
Уравнения регрессии для биомассы ( $\left.W_{\mathrm{st}}\right)$ диатомовых водорослей в стационарной фазе роста накопительной культуры для различных видов фитопланктона

\begin{tabular}{|c|c|c|}
\hline Дата & Уравнение регрессии & $\begin{array}{c}\text { Доверительный } \\
\text { интервал }\end{array}$ \\
\hline \multicolumn{3}{|c|}{ Leptocylindrus danicus } \\
\hline 15.09 .2010 & $W_{\mathrm{st}}=773,6+428 \mathrm{~N}+762,3 \mathrm{P}+439,3 \mathrm{NP}$ & 1567,1 \\
\hline 13.09.2011 & $W_{\mathrm{st}}=1544,4+1107,8 \mathrm{~N}+1297,6 \mathrm{P}+965,1 \mathrm{NP}$ & 2636,3 \\
\hline 12.10.2011 & $W_{\mathrm{st}}=251,4+37 \mathrm{~N}+167,8 \mathrm{P}-15,1 \mathrm{NP}$ & 270,6 \\
\hline \multicolumn{3}{|c|}{ Thalassionema nitzschioides } \\
\hline 5.07 .2010 & $W_{\mathrm{st}}=487,2+273,0 \mathrm{~N}+397,2 \mathrm{P}+282,6 \mathrm{NP}$ & 844,6 \\
\hline 15.09.2010 & $W_{\mathrm{st}}=458,8+428 \mathrm{~N}+458,8 \mathrm{P}+428 \mathrm{NP}$ & 941,4 \\
\hline 12.10 .2011 & $W_{\mathrm{st}}=431,7+56,5 \mathrm{~N}+364,2 \mathrm{P}+71,2 \mathrm{NP}$ & 484,2 \\
\hline \multicolumn{3}{|c|}{ Pseudo-nitzchia pseudodelicatissima } \\
\hline 4.06.2009 & $W_{\mathrm{st}}=4921,6+1300,3 \mathrm{~N}+881,6 \mathrm{P}+\underline{2380,6 \mathrm{NP}}$ & 1486,3 \\
\hline 28.05 .2010 & $W_{\mathrm{st}}=7435,6+6426,7 \mathrm{~N}+6129,7 \mathrm{P}+6366 \mathrm{NP}$ & 17768,7 \\
\hline \multicolumn{3}{|c|}{ Dactyliosolen fragilissimus } \\
\hline 1.06 .2012 & $\begin{aligned} W_{\mathrm{st}}=17679,1 & +\underline{12462,3 \mathrm{~N}}+\underline{11432,5 \mathrm{P}}+ \\
& +\underline{11688,7 \mathrm{NP}}\end{aligned}$ & 2575,3 \\
\hline \multicolumn{3}{|c|}{ Sceletonema costatum } \\
\hline 15.09.2010 & 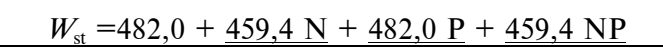 & 233,6 \\
\hline 13.09.2011 & $W_{\mathrm{st}}=1082,3+1023,9 \mathrm{~N}+1013,9 \mathrm{P}+969,1 \mathrm{NP}$ & 983,2 \\
\hline 1.06 .2012 & $W_{\mathrm{st}}=487,2+273,0 \mathrm{~N}+397,2 \mathrm{P}+282,6 \mathrm{NP}$ & 844,6 \\
\hline
\end{tabular}

Диатомовая водоросль Pseudo-nitzchia pseudodelicatissima входит в лидирующий комплекс фитопланктона в весенний и осенний периоды (Паутова и др., 2007; Силкин и др., 2013). В начале эксперимента в июне 2010 г. количество клеток в цепи P. pseudodelicatissima было максимальным - 12. Численность в этот день составляла 1,9·106 кл./л (рис. 4). Наибольшая численность клеток $-3,9 \cdot 10^{6}$ кл./л наблюдалась на 5-й день эксперимента.

K концу эксперимента количество клеток в цепи уменьшалось. В последний день оно составляло 4 клетки, а численность $-2,0 \cdot 10^{6}$ кл./л. Изменения численности клеток и их количества в цепи соответствуют классической кривой накопления численности. В начале эксперимента количество клеток в цепи $P$. pseudodelicatissima было максимальным 18 , численность составляла всего $2,4 \cdot 10^{6}$ кл./л (рис. 5). 
Таблица 3

Уравнения регрессии для количества клеток в цепочке $\left(N_{\mathrm{s}}\right)$ диатомовых водорослей в стационарной фазе роста накопительной культуры природной популяции фитопланктона

\begin{tabular}{|c|c|c|}
\hline Дата & Уравнение регрессии & $\begin{array}{c}\text { Доверительный } \\
\text { интервал }\end{array}$ \\
\hline \multicolumn{3}{|c|}{ Leptocylindrus danicus } \\
\hline 15.09 .2010 & $N_{\mathrm{st}}=4,63-0,63 \mathrm{~N}+4,13 \mathrm{P}-0,13 \mathrm{NP}$ & 2,14 \\
\hline 13.09 .2011 & $N_{\mathrm{st}}=6,4-0,4 \mathrm{~N}+1,6 \mathrm{P}-1,6 \mathrm{NP}$ & 2 \\
\hline 12.10 .2011 & $N_{\mathrm{st}}=6,6+0,1 \mathrm{~N}+3,4 \mathrm{P}-1,1 \mathrm{NP}$ & 4,1 \\
\hline \multicolumn{3}{|c|}{ Thalassionema nitzschioides } \\
\hline 5.07 .2010 & $N_{\mathrm{st}}=10+3,0 \mathrm{~N}+5,0 \mathrm{P}+2,5 \mathrm{NP}$ & 10,1 \\
\hline 15.09 .2010 & $N_{\mathrm{st}}=3,9+1,9 \mathrm{~N}+\underline{3,9 \mathrm{P}}+1,9 \mathrm{NP}$ & 3,6 \\
\hline 12.10 .2011 & $N_{\mathrm{st}}=4,1-0,6 \mathrm{~N}+1,6 \mathrm{P}-0,6 \mathrm{NP}$ & 1,3 \\
\hline \multicolumn{3}{|c|}{ Pseudo-nitzchia pseudodelicatissima } \\
\hline 28.05 .2010 & $N_{\text {st }}=13,9-1,4 \mathrm{~N}-2,9 \mathrm{P}-3,1 \mathrm{NP}$ & 2,8 \\
\hline 15.06 .2010 & $N_{\mathrm{st}}=9,8+1,0 \mathrm{~N}+2,8 \mathrm{P}-1,0 \mathrm{NP}$ & 8,1 \\
\hline \multicolumn{3}{|c|}{ Dactyliosolen fragilissimus } \\
\hline 1.06 .2012 & $N_{\mathrm{st}}=21,1+\underline{9,9 \mathrm{~N}}+\underline{13,6 \mathrm{P}}+\underline{12,4} \mathrm{NP}$ & 4,8 \\
\hline \multicolumn{3}{|c|}{ Sceletonema costatum } \\
\hline 15.09 .2010 & $N_{\mathrm{st}}=4,1+1,4 \mathrm{~N}+\underline{4,1 \mathrm{P}}+1,4 \mathrm{NP}$ & 2,1 \\
\hline 13.09 .2011 & $N_{\mathrm{st}}=7,6+\underline{3,1 \mathrm{~N}}+\underline{4,9 \mathrm{P}}+1,4 \mathrm{NP}$ & 2,4 \\
\hline 1.06 .2012 & $N_{\mathrm{st}}=9,1+\underline{4,6 \mathrm{~N}}+\underline{4,4 \mathrm{P}}+2,9 \mathrm{NP}$ & 3,8 \\
\hline
\end{tabular}

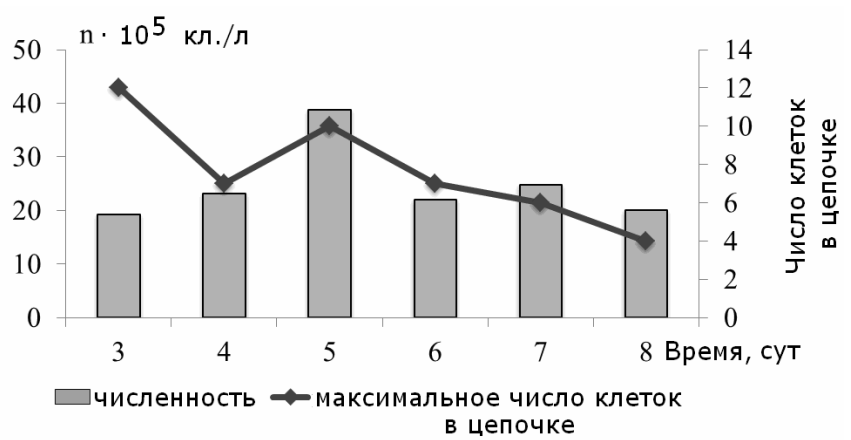

Рис. 4. Численность и количество клеток в цепи Pseudo-nitzchia pseudodelicatissima в эксперименте 15.06.2010 г. В качестве добавки использовали фосфор и азот

Пик численности приходился на третий день эксперимента $\left(5,1 \cdot 10^{6}\right.$ кл./л). Количество клеток в цепи -6 . По мере старения количество клеток в цепи водоросли уменьшалось. На 12-й день эксперимента в накопительной культуре были только одиночные клетки P. pseudodelicatissima, а численность снизилась до $6,7 \cdot 10^{4}$. 


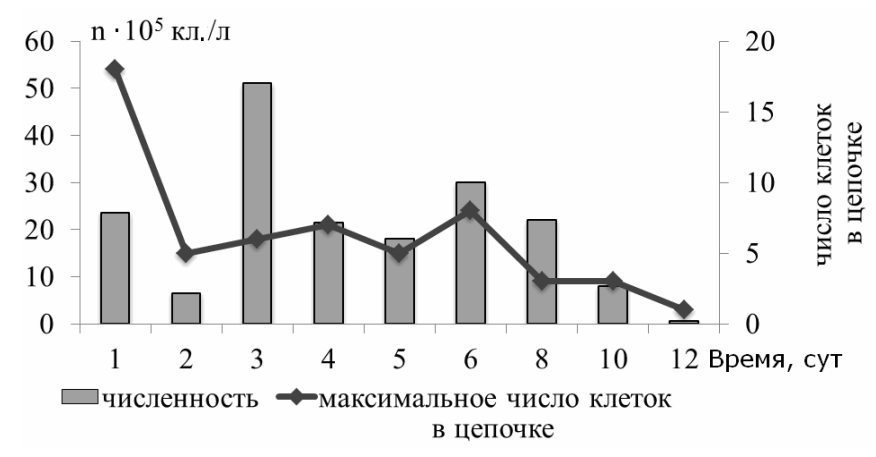

Рис. 5. Численность и количество клеток в цепи Pseudo-nitzchia pseudodelicatissima в эксперименте 28.05.2010 г. В качестве добавки использовали фосфор и азот

Взаимосвязь между количеством клеток в цепи и численностью клеток P. pseudodelicatissima была очень слабой (см. рис. 3, в). Коэффициент детерминации экспоненциальной функции составлял всего 0,2925 , а линейной $-0,1222$.

Уравнения регрессии показали, что в конце весны 2009 г. и начале лета 2010 г. рост $P$. pseudodelicatissima был лимитирован одновременно азотом и фосфором (см. табл. 2).

Уравнение регрессии для количества клеток в цепи $P$. pseudodelicatissima были неинформативны (см. табл. 3). Из них следует, что на увеличение количества клеток в цепи Pseudo-nitzchia pseudodelicatissima в эксперименте 28 мая 2010 г. добавки элементов минерального питания не влияли. Результаты эксперимента 15 июня 2010 г. нельзя считать достоверными, так как сумма коэффициентов регрессии меньше доверительного интервала.

Диатомовая водоросль Thalassionema nitzschioides присутствует в фитопланктоне практически весь год и периодически входит в лидирующий комплекс видов (Паутова и др., 2007; Силкин и др., 2013).

Осенние эксперименты 2010 и 2011 гг. показали, что максимальное накопление биомассы этой водоросли возможно только при одновременной добавке азота и фосфора (см. табл. 2).

Динамика численности и количества клеток в цепи Th. nitzschioides в эксперименте 12 окт. 2011 г. показана на рис. 6. В первый день эксперимента численность клеток составляла $0,8 \cdot 10^{5}$ кл./л, а цепь состояла лишь из двух клеток. В последующие дни наблюдалось развитие популяции и на 6-й день эксперимента количество клеток в цепи достигло максимума - 18. Численность клеток Th. nitzschioides была наибольшей на 7-й день эксперимента $-2,5 \cdot 10^{6}$ кл./л. Далее численность и количество клеток в цепи снижались. К концу опыта це́пи состояли из 4 клеток, численность составляла $6,88 \cdot 10^{5}$ кл./л. Кривые роста чиленности и 
количества клеток в цепи этой водоросли соответствуют классической кривой роста клеток в периодической культуре.

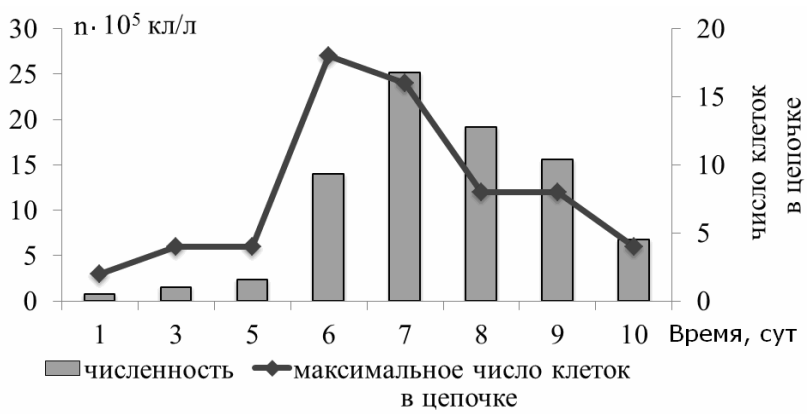

Рис. 6. Численность и количество клеток в цепи Thalassionema nitzschioides в эксперименте 12.10.2011 г. В качестве добавки использовали фосфор

Численность клеток и величина клеточной цепи Th. nitzschioides между собой взаимосвязаны и эта связь наиболее точно описывается экспоненциальной кривой (см. рис. 3, б). Чем больше клеток в цепи, тем больше численность в накопительной культуре фитопланктона. Коэффициент детерминации экспоненциальной линии тренда равен 0,7256 , что свидетельствует о сильной статистической взаимосвязи этих двух признаков. При линейной функции он составляет 0,5969 .

Диатомея Th. nitzschioides доминировала в фитопланктонном сообществе в осенний период. Исходя из уравнений регрессии (см. табл. 2), за рост биомассы Th. nitzschioides ответственна одновременная добавка азота и фосфора в накопительную культуру водорослей.

Из уравнения регрессии для количества клеток в цепи следует, что в сентябре 2010 г. за увеличение количества клеток в цепи ответственны оба элемента минерального питания. В октябре 2011 г. рост числа клеток в цепях диатомеи Th. nitzschioides был вызван добавкой фосфора (см. табл. 3).

Диатомовая водоросль Sceletonema costatum была постоянной составляющей лидирующего комплекса во второй половине прошлого века. Динамика количества клеток в цепи и численности клеток диатомеи $S$. costatum в июне 2012 г. показала их скоррелированность (рис. 7). Максимальное количество клеток в цепи (20) совпадает с наибольшей численностью - 5,8·10 уменьшение количества клеток цепи $S$. costatum, в последний день эксперимента максимальное количество составляло 8 клеток.

Численность клеток и размеры цепей $S$. costatum имеют сильную статистическую взаимосвязь, которая носит экспоненциальный характер (коэффициент детерминации 0,722 ) (см. рис. 3, г). При линейной функции коэффициент равен 0,6063. 
Рассчитанные уравнения регрессии показывают, что интенсивный рост биомассы $S$. costatum происходит лишь после совместной добавки элементов минерального питания (азота и фосфора) (см. табл. 2).

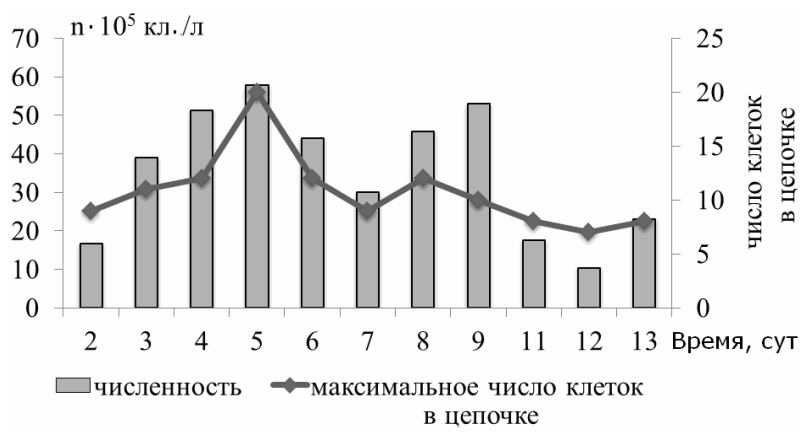

Рис. 7. Численность и количество клеток в цепи Sceletonema costatum в эксперименте 1.06.2012 г. В качестве добавки использовали фосфор и азот

Из уравнений для количества клеток в цепи $S$. costatum следует, что совместная добавка этих элементов приводит к увеличению количества клеток в цепи в летне-осенний период (см. табл. 3).

Крупноклеточная диатомея Dactyliosolen fragilissimus периодически входит в лидирующий комплекс видов в северо-восточной части Черного моря (Паутова и др., 2007; Силкин и др., 2013).

Рост биомассы этого вида наиболее интенсивен в четвертом варианте эксперимента, где добавляли оба элемента минерального питания (рис. 8). Максимальное количество клеток в цепи и численности за весь период эксперимента наблюдали на 3-й день - 52 клетки в цепи и $1,2 \cdot 10^{7}$ кл./л соответственно. В последний день эксперимента количество клеток в цепи составляло 14 клеток, численность $-4,4 \cdot 10^{6}$ кл./л.

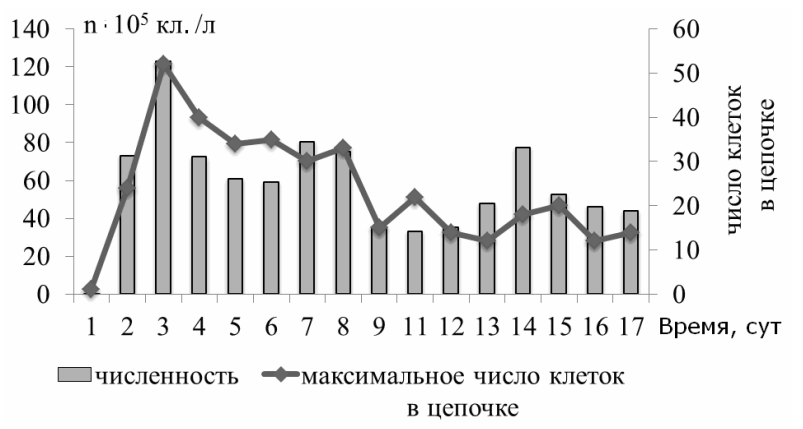

Рис. 8. Численность и количество клеток в цепи Dastyliosolen fragilissimus в эксперименте 1.06.2012 г. В качестве добавки использовали фосфор и азот 
Число клеток в цепи диатомеи D. fragilissimus практически пропорционально численности (см. рис. 3 , д). Коэффициент детерминации линейной функции показывает достаточно сильную взаимосвязь этих двух признаков $(0,7058)$. При экспоненциальной функции коэффициент детерминации составлял 0,6227.

Во втором варианте эксперимента с добавкой азота и фосфора максимальное количество клеток в цепи D. fragilissimus приходилось на 3-й день - 62 клетки, численность $1,1 \cdot 10^{7}$ кл./л (рис. 9). В последний день эксперимента численность клеток была $0,6 \cdot 10^{7}$ кл./л, а число клеток в цепи -29.

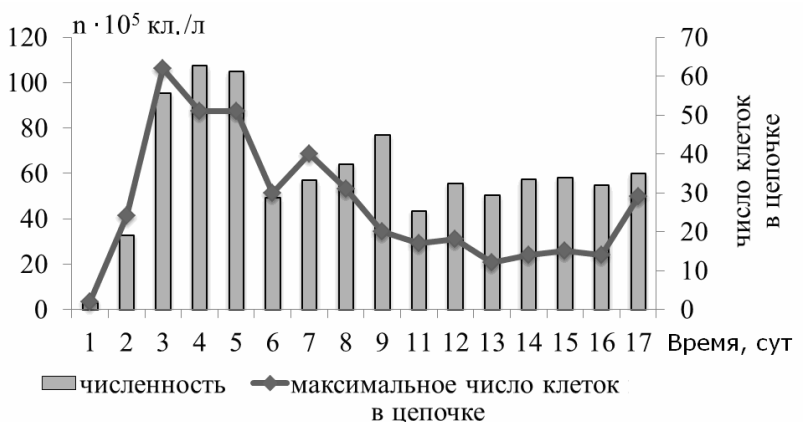

Рис. 9. Численность и количество клеток в цепи Dactyliosolen fragilissimus в эксперименте 1.06.2012 г. В качестве добавки использовали фосфор и азот

Статистическая взаимосвязь между количеством клеток в цепи и численностью клеток D. fragilissimus значительна. Коэффициент детерминации экспоненциальной функции составляет 0,8741 , а линейной 0,9082 (см. рис. 3, e).

Из уравнений регрессии следует, что рост биомассы и увеличение количества клеток в цепи D. fragilissimus в июне 2012 г. вызваны добавкой азота и фосфора (см. табл. 2, 3).

\section{Обсуждение}

Экспериментальные исследования с накопительной культурой позволяют выявить лимитирующие факторы продукционного процесса в целом и определить факторы-регуляторы видовой структуры фитопланктонного сообщества. Используя уравнение регрессии, мы смогли определить влияние элементов минерального питания на биомассу и количество клеток в цепи доминирующих видов фитопланктона. Для увеличения биомассы всех диатомовых водорослей в фитопланктонном сообществе необходимо одновременное повышение концентраций азота и фосфора в среде (см. табл. 2). Существующие на сегодняшний день концентрации этих веществ в море недостаточны для интенсивного роста этих водорослей. Одновременная добавка азота и фосфора, в которой отношение этих веществ близко к соотношению Редфилда устранит лимитацию 
ростовых процессов. На это указывалось раннее в работах с фитопланктоном Черного моря (Силкин и др., 2009).

Из уравнений регрессии для количества клеток в цепи следует, что число клеток в цепи Leptocylindrus danicus и Thalassionema nitzschioides увеличивается при повышении концентрации фосфора в накопительной культуре (см. табл. 3). Для Pseudo-nitzschia pseudodelicatissima максимальный эффект достигается при отсутствии высоких концентраций азота и фосфора в среде. У Dactyliosolen fragilissimus наблюдалось интенсивное накопление клеток в цепи при одновременной добавке элементов минерального питания. В сентябре 2010 г. увеличение числа клеток в цепи диатомеи Sceletonema costatum происходило в результате добавки фосфора в накопительную культуру. В сентябре 2011 г. и в июне 2012 г. только одновременная добавка элементов минерального питания влияла на количество клеток в цепи Sceletonema costatum.

Можно предположить различные причины образования цепей диатомовых клеток. Некоторые авторы объясняют это недостатком кремния, скученностью и экстремальными рН (Feldt et al., 1973; Barber, Carter, 1981). Так, уменьшение длины Asterionella formosa в некоторых озерах Канады было связано с ограничением кремния в среде (Kling, 1993). С нашей точки зрения, наиболее вероятной причиной формирования длинных цепей является разница скоростей роста биомассы, деления клеток и их разделения. В случае постоянства размеров отдельной клетки удельная скорость роста биомассы будет равна скорости деления клеток. При высоких скоростях роста $(\mu)$, превосходящих скорость разделения клеток (q), будет формироваться цепочка. И чем больше разница в этих процессах, тем больше количество клеток в цепи. Удельная скорость роста определяется большим количеством факторов, среди которых минеральное питание играет существенную роль. Это подтверждают данные экспериментов, в которых количество клеток в цепи $S$. costatum повышалось с увеличением концентрации элементов минерального питания и температуры от 6 до $17^{\circ} \mathrm{C}$ (Takabayashi et al., 2006).

При добавлении лимитирующего элемента в накопительную культуру фитопланктона происходит увеличение удельной скорости роста. Она намного превышает скорость разделения клеток $(\mu>>\mathrm{q})$, поэтому наблюдаются длинные клеточные цепи. Со временем удельная скорость роста снижается, но всё же превышает скорость разделения $(\mu>\mathrm{q})$. Количество клеток в цепи уменьшается. Появление в популяции одиночных клеток свидетельствует о том, что скорость разделения превышает скорость роста $(\mu<\mathrm{q})$. А концентрация элементов минерального питания в среде снижается до уровня, не способного поддерживать высокие скорости роста клеток в цепи, что наблюдается к концу эксперимента.

В наших экспериментах показано, что удельная скорость роста для диатомей $L$. danicus и Th. nitzschioides повышается при добавлении только фосфора. Для $S$. costatum и $D$. fragilissimus увеличение количества клеток в цепи зависит от совместной добавки азота и фосфора (см. табл. 3). 
Добавки элементов минерального питания не влияют на изменения в клеточной цепи диатомеи $P$. pseudodelicatissima.

Эксперименты позволили оценить взаимосвязь численности клеток и количества клеток в цепи. Таким образом, диатомовые водоросли Th. nitzschioides, D. fragilissimus и S. costatum имеют высокий коэффициент корреляции для этих двух признаков. Для L. danicus взаимосвязь между численностью и количеством клеток в цепи отсутствует, а для P. pseudodelicatissima корреляция является очень слабой.

Результаты данных исследований убедительно показывают, что концентрации элементов минерального питания (азота и фосфора) регулируют морфологическую структуру и продукционные свойства доминирующих видов фитопланктона шельфовых вод северо-восточной части Чёрного моря.

Таким образом, увеличение концентраций азота и фосфора приводит к интенсификации роста биомассы всех диатомовых водорослей. У диатомей Sceletonema costatum и Dactyliosolen fragilissimus увеличение количества клеток в цепи зависит от совместной добавки азота и фосфора, в то время как у диатомеи $P$. pseudodelicatissima такая зависимость не наблюдается. Установлена взаимосвязь численности клеток и их количества в цепи. Показано, что диатомовые водоросли Th. nitzschioides, D. fragilissimus и $S$. costatum имеют высокий коэффициент детерминации этих двух признаков, а для $P$. pseudodelicatissima корреляция является очень слабой. Для L. danicus взаимосвязь между численностью клеток и количеством клеток в цепи отсутствует.

\section{СПИСОК ЛИТЕРАТУРЫ}

Киселев И.А. Планктон морей и континентальных водоемов. - Л.: Наука, 1969. - Т. 1. $-657 \mathrm{c}$.

Максимов В.Н., В.Д. Федоров. Применение методов математического планирования эксперимента при отыскании оптимальных условий культивирования организмов. - М.: Изд-во МГУ, 1969. - 128 с.

Микаэлян А.С., Силкин В.А., Паутова Л.А. Развитие популяции кокколитофорид в Черном море: межгодовые и многолетние изменения // Океанология. -2011 . 51, № 1. - С. 45-53.

Паутова Л.А., Микаэлян А.С., Силкин В.А. Структура планктонных фитоценов шельфовых вод северо-восточной части Черного моря в период массового развития Emiliania huxleyi в 2002-2005 гг. // Там же. - 2007. - 47, № 3. - С. 408-417.

Прошкина-Лавренко А.И. Диатомовые водоросли планктона Черного моря. - М.: Издво АН СССР, 1955. - 224 с.

Силкин В.А., Хайлов К.М. Биоэкологические механизмы в аквакультуре. - Л.: Наука, 1988. - $230 \mathrm{c}$.

Силкин В.А., Паутова Л.А., Лифанчук А.В. Физиологические механизмы регуляции структуры морских фитопланктонных сообществ // Физиол. раст. - 2013. - 60, № 4. - С. 574-581. 
Силкин В.А., Паутова Л.А., Микаэлян А.С. Рост кокколитофориды Emiliania huxleyi (Lohmann) Hay et Mohler в северо-восточной части Черного моря, лимитированный концентрацией фосфора // Альгология. - 2009. - 19, № 2. - С. 135-144.

Barber H.G., Carter J.R. Observations on some deformities found in British diatoms // Microscopy. - 1981. - 34. - P. 214-226.

Feldt L.E., Stoermer E.F., Schelske C.L. Occurrence of morphologically abnormal Synedra populations in Lake Superior phytoplankton // Proc. $16^{\text {th }}$ Conf. Great Lakes Res. 1973. - P. 34-39.

Kling H.J. Asterionella formosa Ralfs: the process of rapid size reduction and its possible ecological significance // Diatom Res. - 1993. - 8. - P. 475-479.

Redfield A.C. On the proportion of organic derivatives in sea water and their relation to composition of plankton // James Johnstone Memorial Volume. - Liverpool: Univ. Press Liverpool, 1934. - P. 177-192.

Redfield A.C., Ketchum B.H., Richards F.A. The influence of organisms on the composition of sea water // Sea. - 1963. - 2. - P. 26-77.

Takabayashi Misaki, Lew Kevin, Johnson Amber et al. The effect of nutrient availability and temperature on chain length of the diatom, Sceletonema costatum // J. Plankt. Res. 28, N 9. - P. 831-840.

Поступила 19 февраля 2013 г. Подписала в печать Г.Г. Миничева

\section{A.V. Lifanchuk}

Southern Branch of the P.P. Shirshov Institute of Oceanology RAS,

Okeanologiya, Gelegdzhik 353467, Krasnodar Region, Russia

e-mail: lifanchuk.anna@mail.ru

\section{MORPHOLOGICAL STRUCTURE OF DOMINATING SPECIES OF DIATOMS IN THE NORTH-EASTERN BLACK SEA}

Influence of mineral nutrition element concentration upon the morphological structure (number of cells in the chain) and productional characteristics of leading complex of phytoplankton in the North-Eastern Black Sea in 2009-2012 was revealed. In the tests with nitrogen and phosphorus addition it was shown that increasing of the number of cells in the chain of Dactyliosolen fragilissimus (Bergon) Hasle and Sceletonema costatum (Grev.) Cleve diatoms took place under a high concentration of both mineral nutrition elements. Growing of phosphorus concentration and small content of nitrogen resulted in increasing of cellular chain of Leptocylindrus danicus Cleve and Thalassionema nitzschioides Grunow. Addition of mineral nutrition elements has not influenced on the change of cellular chain of Pseudo-nitzschia pseudodelicatissima (Hasle) Hasle diatom. Experiments have shown a close interconnection between cell quantity and cell number in the chain of Th. nitzschioides, D. fragilissimus and S. costatum. For L. danicus the correlation between these parameters was absent, and for $P$. pseudodelicatissima the correlation was very weak. Intensification of growth of diatom biomass was observed when nitrogen and phosphorus were added simultaneously.

Keyw ords: phytoplankton, the Black Sea, nitrogen and phosphorus, length of cellular chain. 